\title{
Sistem Informasi Dokumentasi Berbasis Web pada Kantor Notaris/PPAT Merliansyah, S.H., M.Kn
}

\author{
Documentation Information System Based Web at Office \\ Notaris/PPAT Merliansyah, S.H., M.Kn \\ Nur Amalia Rizka Aktori ${ }^{1}$, Siti Nabila Nada Tiara $^{2}$, Mulyati ${ }^{3}$ \\ ${ }^{1,2,3}$ STMIK GI MDP; Jl. Rajawali No. 14 Palembang, +62(711) 376400 \\ ${ }_{1,2,3}$ Program Studi Sistem Informasi, STMIK GI MDP, Palembang \\ e-mail: ${ }^{* 1}$ nuramaliarz@mhs.mdp.ac.id, ${ }^{2}$ sitinabila.nadatiara@mhs.mdp.ac.id, \\ ${ }^{3}$ muliati@mdp.ac.id
}

\begin{abstract}
Abstrak
Kantor Notaris/PPAT Merliansyah, S.H., M.Kn merupakan perusahaan yang bergerak dibidang hukum, terkait dengan pelayanan hukum kepada masyarakat sebagai salah satu kebutuhan masyarakat khususnya dalam pembuatan akta-akta baik itu secara Notariil maupun PPAT yang diberikan kepada pihak klien dengan proses pengajuan sehingga klien harus datang ke kantor. Kantor ini juga memiliki kendala pada proses dokumentasi akta yang belum terkoordinir dalam lemari arsip serta belum adanya pemantaun pengelolaan surat masuk dan surat keluar. Dalam hal ini dengan adanya permasalahan yang dihadapi oleh kantor maka dibuat sistem informasi dokumentasi pada Kantor Notaris/PPAT Merliansyah, S.H., M.Kn. Metodologi yang digunakan adalah metodologi iterasi yang terdiri dari fase perencanaan, analisis masalah, perancangan, implementasi, dan pemeliharaan. Aplikasi ini menggunakan bahasa pemograman PHP dan menggunakan program Notepad++ serta MySQL sebagai basis data. Dengan adanya aplikasi ini, dapat membantu proses pengajuan pembuatan akta dalam penyampaian informasi serta membantu kantor dalam meningkatkan pelayanan terhadap klien.
\end{abstract}

Kata kunci : Sistem Informasi, Dokumentasi, Notaris, Iterasi, MySQL, PHP

\begin{abstract}
The Office Notaris / PPAT Merliansyah, SH, M.Kn is a company engaged in the law, related to legal services to the community as one of the needs of the community, especially in the making of both the notarial deed and PPAT given to the client with the submission process so that the client must come to the office. This office also has problems in the documentation process of the deed that has not been coordinated in the file cabinet and there is no monitoring of incoming and outgoing mail management. In this case, with the problems faced by the office, a documentation information system was made at the Notary Office / PPAT Merliansyah, S.H., M.Kn. The methodology used is the iteration methodology which consists of the planning, problem analysis, design, implementation, and maintenance phases. This application uses the PHP programming language and uses Notepad ++ and MySQL as a database. With this application, it can help the process of filing a deed in the delivery of information and help the office in improving services to clients.
\end{abstract}

Keywords : Information Systems, Documentation, Notary, Iteration, MySQL, PHP 


\section{PENDAHULUAN}

Berkembangnya teknologi informasi sekarang ini membuat hampir semua aspek kehidupan tidak dapat jauh dari penggunaan perangkat komputer mulai dari bidang akademik, sosial, bidang hukum dan yang lainnya. Salah satu contoh bidang hukum yang menggunakan teknologi informasi adalah Kantor Notaris/PPAT Merliansyah, S.H., M.Kn yang beralamat di Jalan Rudus No. 40 Sekip Ujung, Kota Palembang. Menurut Pasal 1 angka 1 pada UUJN mendefinisikan Notaris merupakan Pejabat Umum yang memiliki wewenang untuk membuat Akta Otentik mengenai semua perjanjian, perbuatan dan ketetapan yang diharuskan oleh peraturan perundang-undangan. Berdasarkan kegiatannya Kantor Notaris/PPAT Merliansyah, S.H., M.Kn memiliki banyak dokumen yang harus disimpan, meliputi dokumen Pendirian Perseroan Terbatas (PT), Pendirian Yayasan, Pendirian Koperasi, Kuasa untuk menjual, Perjanjian Sewa-Menyewa, perjanjian Jual-Beli, Keterangan Hak Waris, Pengoperan dan Penyerahan Hak, Wasiat, Pendirian CV, Pengakuan Hutang, Perjanjian Kredit, Pemberian hak tanggungan, Perjanjian Kerja Sama, Kontrak Kerja, Legalisasi maupun Waarmerking Akta, surat masuk dan surat keluar. Dokumen tersebut dijadikan sebagai sarana bukti rekapitulasi dan dokumentasi yang akan menjadi laporan bulanan kantor sedangkan untuk laporan wajib perbulan ke Kementrian Hukum dan HAM juga meliputi dokumen tersebut kecuali surat masuk dan surat keluar.

Selama ini proses pembuatan akta mulai dari mengharuskan klien datang ke kantor untuk mengetahui syarat yang diperlukan, terkadang syarat yang diberikan belum sesuai dan pihak administrasi harus menunggu klien untuk melengkapi persyaratan tersebut sehingga klien harus datang berkali-kali ke kantor untuk mengetahui informasi dan memenuhi syarat pembuatan akta. Jika sudah lengkap dan sesuai maka dilakukan pengecekan pajak bagi akta tertentu, selanjutnya membuat perjanjian untuk cek lapangan, lalu ke tahap penentuan biaya, setelah itu akan dilakukan proses pembuatan akta dengan waktu yang tidak menentu, setelah akta selesai maka bagian administrasi akan menghubungi klien untuk mengambil salinan akta, dan akta asli (MINUTA) akan didokumetasi kan. Proses dokumentasi yang dilakukan dimulai dari pencatatan di buku besar, penyimpanan di ruang arsip, dan rekap arsip yang akan dijadikan laporan perbulan. Selanjutnya jika dokumen yang di arsip memasuki usia 5 tahun maka akan dipindahkan ke gudang arsip di awali terbitnya berita acara untuk mengetahui pegawai yang terlibat lalu baru dilakukan pengecekan ulang ke setiap dokumen yang mengakibatkan memakan waktu kinerja. Sedangkan mengenai dokumentasi proses disposisi surat masuk belum terpantau dengan baik yang mengakibatkan surat tidak sampai ketujuan sehingga menyebabkan hilangnya informasi dari surat yang masuk tersebut, sementara surat keluar dimulai dari pembuatan konsep di microsoft word setelah itu akan dicetak dan dikirimkan ke alamat tujuan. Pada saat pembuatan nomor surat keluar bagian administrasi harus melakukan pengecekan terhadap penomoran terakhir dari surat yang dikirim sebelumnya. Hal ini mengakibatkan terkadang terjadinya penomoran yang sama pada surat yang berbeda sehingga berpengaruh pada saat pelaporan surat masuk dan surat keluar yang mengakibatkan kesalahan pecatatan. Penerapan tersebut, menjadikan proses dokumentasi masih kurang efektif dan efisien di antaranya adalah pencarian dokumen yang memakan waktu cukup lama, terlebih kesulitan apabila dokumen tersebut sudah lebih dari 5 tahun karena diletakkan di gudang arsip dan status dokumen yang belum ada pemantauan oleh pegawai.

Dengan mengamati sistem yang sudah berjalan pada Kantor Notaris/ PPAT Merliansyah, S.H, M.Kn membutuhkan sistem yang lebih terkomputerisasi untuk mempermudah pekerjaan agar tidak berulang kali dalam melakukannya sedangkan data dokumen yang akan didokumentasikan nantinya akan lebih akurat. Berdasarkan uraian latar belakang diatas, maka dilakukan penelitian dengan judul "Sistem Informasi Dokumentasi Berbasis Web Pada Kantor Notaris/PPAT Merliansyah, S.H, M.Kn”. 


\section{TINJAUAN UMUM}

Di dalam bab ini, penulis akan membahas teori yang erat hubungannya dengan judul. Teori-teori ini merupakan landasan bagi penulis dalam mengadakan penelitian, menganalisa dan menafsirkan masalah yang timbul.

\subsection{Rekapitulasi}

Rekapitulasi adalah ringkasan; ikhtisar; ringkasan isi atau ikhtisar pada akhir laporan atau akhir hitungan;pembuatan rincian data yang bercampur. (Kamus Besar Bahasa Indonesia diakses pada 19 September 2019 19:33WIB)[5]

\subsection{Dokumentasi}

Menurut BAPENPEMDA KEMENDIKBUD (2011, h.101) Dokumentasi adalah pemilihan, pengolahan, pengumpulan dan penyimpanan informasi di bidang pengetahuan. Dokumentasi merupakan pengumpulan bukti dan keterangan seperti guntingan koran, gambar, dan kutipan lain.[6]

\subsection{Arsip}

Arsip merupakan dokumen tertulis, biasanya dikeluarkan oleh instansi resmi, disimpan dan dipelihara di tempat khusus untuk referensi; simpanan surat-surat pertinggal; tempat menyimpan surat-surat yang masih perlu.[6]

\subsection{Sistem}

Menurut George M. Marakas dan James A. O'Brien (2017, h.27) Sistem diartikan sebagai kumpulan perangkat komponen yang saling berkait, dengan batasan yang jelas, untuk bekerja sama mencapai tujuan tertentu dengan menerima masukan yang menghasilkan keluaran yang terorganisasi dalam proses transformasi.[7]

\subsection{Informasi}

Menurut Tata Sutabri (2016, h.25) Dalam buku yang berjudul Sistem Informasi Manajemen, Informasi merupakan data yang diklasifikasi, diolah atau diinterpretasi yang berguna untuk pengambilan keputusan.[9]

\subsection{Sistem informasi}

Menurut George M. Marakas dan James A. O’Brien (2017, h.6) Sistem Informasi (SI) adalah kombinasi antara perangkat keras, orang-orang, perangkat keras, perangkat lunak, jaringan komunikasi, sumber daya data, kebijakan dan prosedur dalam menyimpan, mengubah, mendapatkan kembali, dan menyebarkan informasi dalam suatu organisasi.[7]

\subsection{Analisis PIECES}

Untuk mengindentifikasi masalah, maka harus dilakukan analisis pada kinerja, informasi, ekonomi, keamanan aplikasi, efisiensi, dan pelayanan pelanggan. Panduan ini dikenal dengan analisis PIECES (performance, information, economy, control, efficiency, dan services). Dari analisis yang dilakukan biasanya terdapat beberapa masalah utama. Hal ini penting Karena terkadang yang muncul di permukaan bukan masalah utama, tetapi hanya gejala masalah utama saja (Hanif Al Fatta, 2007 , h.51).[4]

\subsection{Usecase Diagram}

Menurut Rosa A.S dan M. Shalahuddin (2013, h.155) Use case atau diagram use case merupakan pemodelan untuk kelakukan (behavior) sistem informasi yang akan dibuat. Use case mendeskripsikan sebuah interaksi antara satu atau lebih aktor dengan sistem informasi yang akan dibuat. Secara kasar, use case digunakan untuk mengetahui fungsi apa saja yang ada di dalam sebuah sistem informasi dan siapa saja yang berhak menggunakan fungsi-fungsi itu.[1] 


\subsection{Data Flow Diagram}

Menurut Rosa A.S dan M. Shalahuddin (2013, h.69) DFD adalah representasi grafik yang menggambarkan aliran informasi dan tranformasi informasi yang diaplikasikan sebagai data yang mengalir dari masukan (input) dan keluaran (output).[1]

\subsection{Entity Relationship Diagram}

Menurut Rosa A.S dan M. Shalahuddin (2013, h.50) ERD adalah pemodelan awal basis data yang digunakan adalah menggunakan Entity Relationship Diagram (ERD). ERD dikembangkan berdasarkan teori himpunan dalam bidang matematika dan digunakan untuk pemodelan basis data relasional.[1]

\subsection{MySQL}

Menurut Frangky Rawung (2017, h.24) MySQL adalah sebuah perangkat lunak manajemen database yang open source untuk digunakan sebagai menambahkan, mengubah, menghapus, dan menampilkan data.[8]

\subsection{Basis Data}

Menurut Fathansyah (2018, h.2) Basis Data terdiri atas 2 kata, yaitu Basis dan Data. Basis kurang lebih dapat diartikan sebagai markas atau gudang, tempat bersarang/berkumpul. Sedangkan Data adalah representasi fakta dunia nyata yang mewakili suatu objek seperti manusia (pegawai, siswa, pembeli, pelanggan), barang, hewan, peristiwa, konsep, keadaan, dan sebagainya, yang diwujudkan dalam bentuk angka, huruf, simbol, teks, gambar, bunyi, atau kombinasinya.[3]

\subsection{XAMPP}

Menurut Gede Rasben Dantes, Komang Setemen dkk (2019, h.98) Xampp adalah aplikasi yang memungkinkan komputer windows Anda digunakan sebagai web server. Xampp juga dapat diartikan sebagai sebuah paket software yang berisi Apache HTTP server dan MySQL dan mendukung program PHP dan Perl dan berjalan di beberapa Sistem Operasi(windows, MAC, Linux, BSD).[2]

\section{METODE PENELITIAN}

Metodologi yang digunakan adalah metodologi iterasi, yaitu: tahap perencanaan sistem, tahap analisis sistem, tahap perancangan sistem, tahap pembuatan sistem, serta tahap implementasi sistem dan tahap pemeliharaan sistem. Namun, pada penelitian saat ini tahap pemeliharaan sistem tidak digunakan. Berikut penjelasan dari tahap-tahap yang terdapat pada metodologi iterasi :

1. Fase Perencanaan

Hal yang dilakukan pada fase ini adalah mendefinisikan masalah untuk menentukan ruang lingkup sistem yang akan dibangun. Mempersiapkan jadwal dan melakukan pengumpulan data-data penting dari perusahaan.

2. Fase Analisis

Data - data yang telah dikumpul kan dari kebutuhan yang telah di harapkan user melalui wawancara, survey atau pun diskusi akan di analisis dan di dokumentasi untuk kebutuhan pada tahap selanjutnya.

3. Fase Perancangan

Pada fase ini bertujuan untuk memberikan gambaran apa yang seharusnya dikerjakan dan bagaimana tampilan antarmuka aplikasi. Serta menyangkut konfigurasi komponen komponen perangkat keras dan perangkat lunak yang dibutuhkan sistem tersebut sehingga setelah instalasi sistem akan benar-benar memuaskan rancang bangun sudah ditetapkan pada tahapan analisis sistem. 
4. Fase Implementasi

Pada fase ini akan dilakukan persiapan sistem ke konversi sistem yang baru, pelatihan, dan pengoprasian sistem. Hasil dari tahapan perancangan sistem akan diubah menjadi bentuk yang dimengerti dalam bentuk pemrograman. Selain itu juga pada tahapan ini akan dilakukan pengujian sistem atau pemeriksa an apakah sistem yang dibuat telah memenuhi kebutuhan atau belum.

5. Fase Pemeliharaan

Fase pemeliharaan merupakan fase terakhir dalam metode iterasi, aplikasi yang sudah dibuat akan dijalankan serta dilakukan pemeliharaan. Pemeliharaan termasuk dalam memperbaiki kesalahan yang tidak ditemukan pada fase sebelumnya. Fase ini merupakan perbaikan implementasi unit sistem dan peningkatan performa sistem.

\section{HASIL DAN PEMBAHASAN}

\subsection{Analisis Permasalahan}

Tabel 1. PIECES

\begin{tabular}{|l|l|}
\hline \multicolumn{1}{|c|}{ PIECES } & \multicolumn{1}{|c|}{ Permasalahan } \\
\hline Performance & $\begin{array}{l}\text { Butuh waktu yang lama dalam proses pencarian dokumen, } \\
\text { kesalahan pada saat penyesuaian data, dan lambatnya tindak } \\
\text { lanjut disposisi dalam pengelolaan surat masuk. }\end{array}$ \\
\hline Information & $\begin{array}{l}\text { Informasi sering terjadi keterlambatan, kurang nya informasi } \\
\text { yang di terima oleh pemohon, dan kekeliruan dalam buku } \\
\text { pencatatan surat. }\end{array}$ \\
\hline Economic & $\begin{array}{l}\text { Resiko akibat kerusakan arsip dikarenakan umur arsip dan dalam } \\
\text { rekap pendapatan masih manual. }\end{array}$ \\
\hline Controlling & $\begin{array}{l}\text { Sulitnya mengetahui proses pencatatan dan rekapitulasi dokumen, } \\
\text { adanya nomor yang sama pada surat keluar yang berbeda. }\end{array}$ \\
\hline Eficiency & $\begin{array}{l}\text { Pembuatan akta, klien harus datang langsung untuk mengetahui } \\
\text { syarat -syarat pengajuan, pencari an data di ruang arsip } \\
\text { membutuhkan waktu untuk mencari dan juga untuk merekap lagi } \\
\text { di buku pencatatan. }\end{array}$ \\
\hline Service & $\begin{array}{l}\text { Pelayanan menjadi terhambat karna klien harus beberapa kali } \\
\text { datang ke kantor untuk mengetahui proses akta, proses surat } \\
\text { masuk tidak sampai ke penerima dan terdapat penomoran ganda } \\
\text { di surat keluar, Keluhan pelanggan dalam pembuatan akta dan } \\
\text { pegawai pun menunggu syarat lengkap untuk pembuatan akta. }\end{array}$ \\
\hline
\end{tabular}

\section{4..2 Analisis Kebutuhan}

\subsubsection{Kebutuhan Fungsional}

Berikut adalah usecase diagram dari Sistem Informasi Dokumentasi Berbasis Web pada Kantor Notaris/PPAT Merliansyah, S.H., M.Kn. 


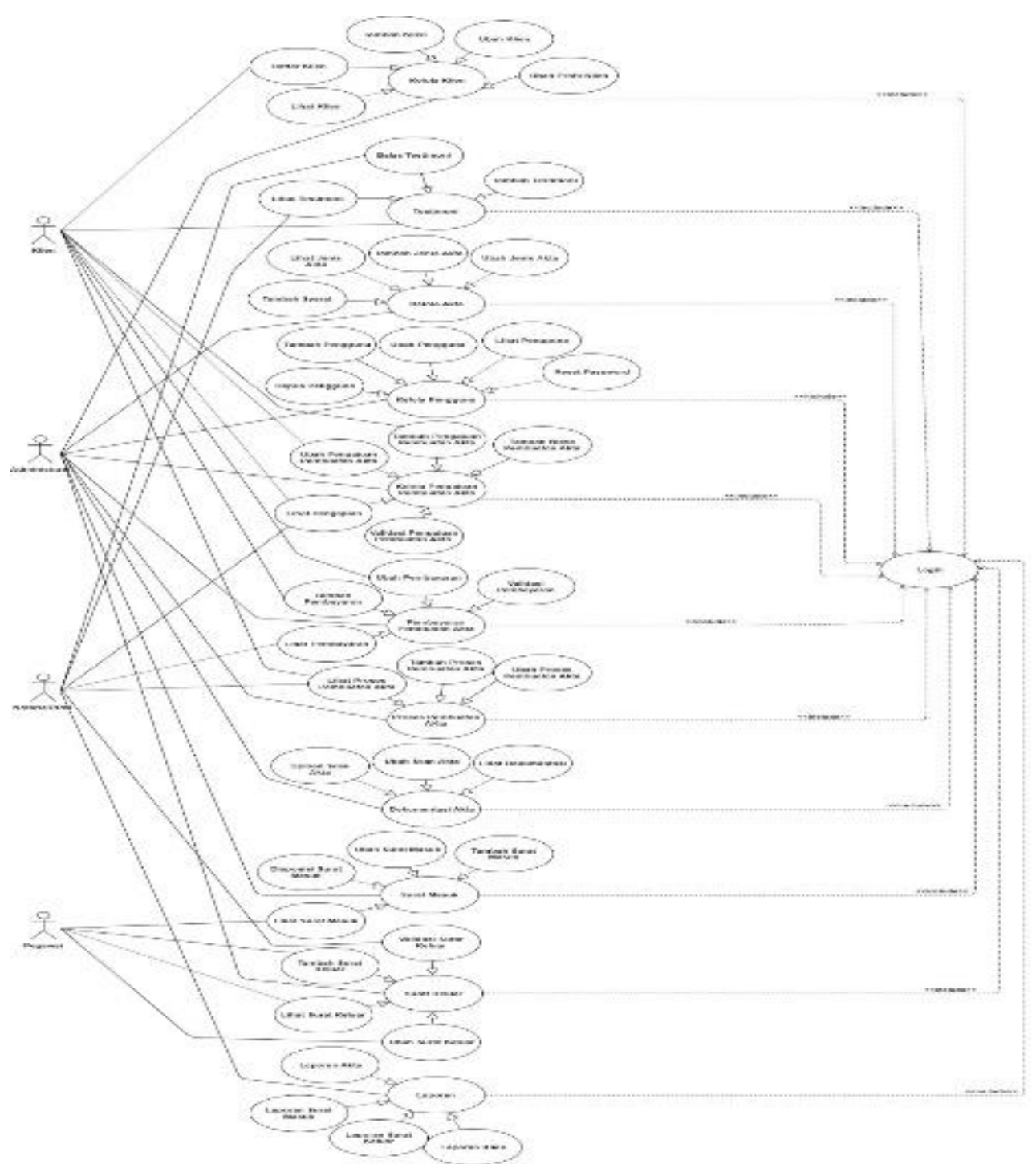

Gambar 1. Usecase Diagram

\subsection{Diagram Konteks}

Berikut adalah gambar diagram konteks pada Sistem Informasi Dokumentasi Berbasis Web pada Kantor Notaris/PPAT Merliansyah, S.H., M.Kn. 


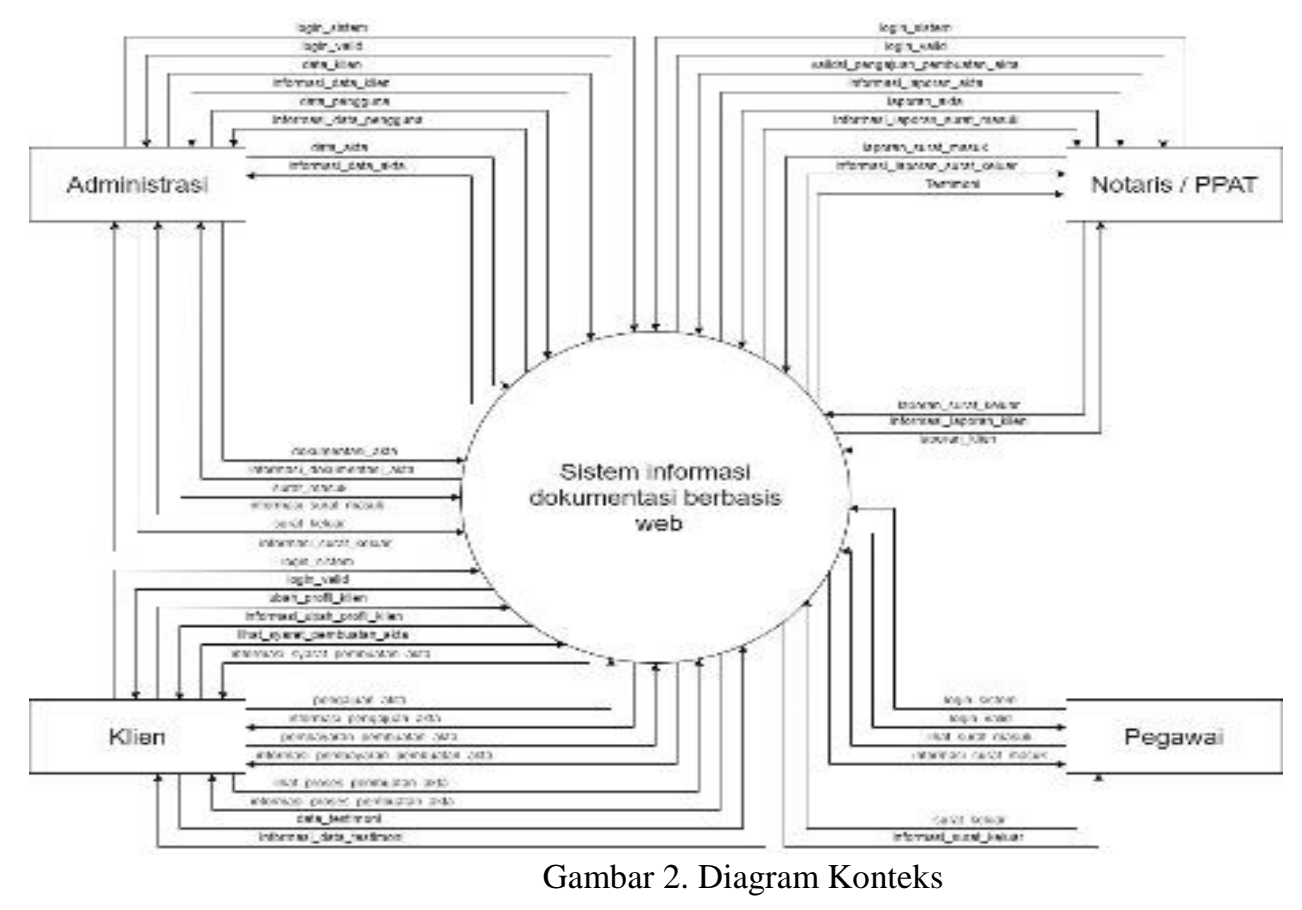

\subsection{Diagram Dekomposisi}

Berikut adalah gambar diagram dekomposisi pada Sistem Informasi Dokumentasi Berbasis Web pada Kantor Notaris/PPAT Merliansyah, S.H., M.Kn

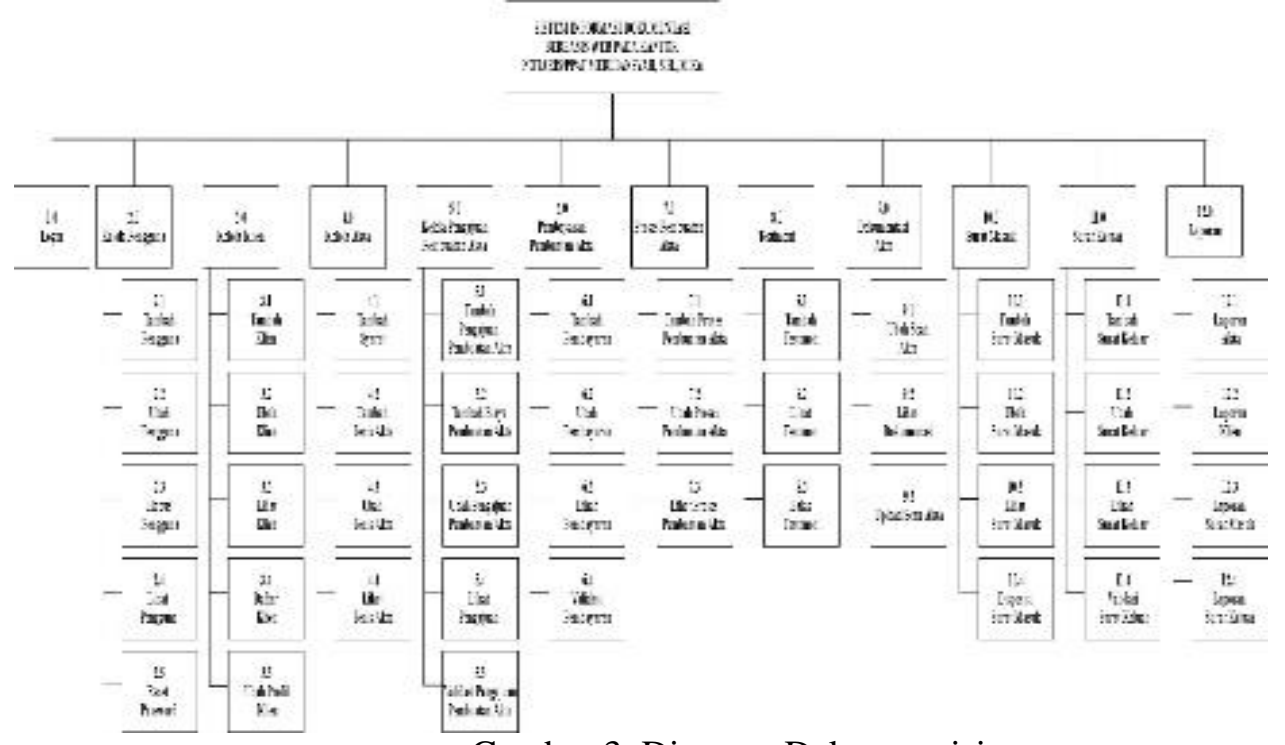

Gambar 3. Diagram Dekomposisi

\subsection{Data Flow Diagram (DFD) Level Nol Logis}

Berikut adalah gambar Data Flow Diagram (DFD) Level Nol Logis pada Sistem Informasi Dokumentasi Berbasis Web pada Kantor Notaris/PPAT Merliansyah, S.H., M.Kn 


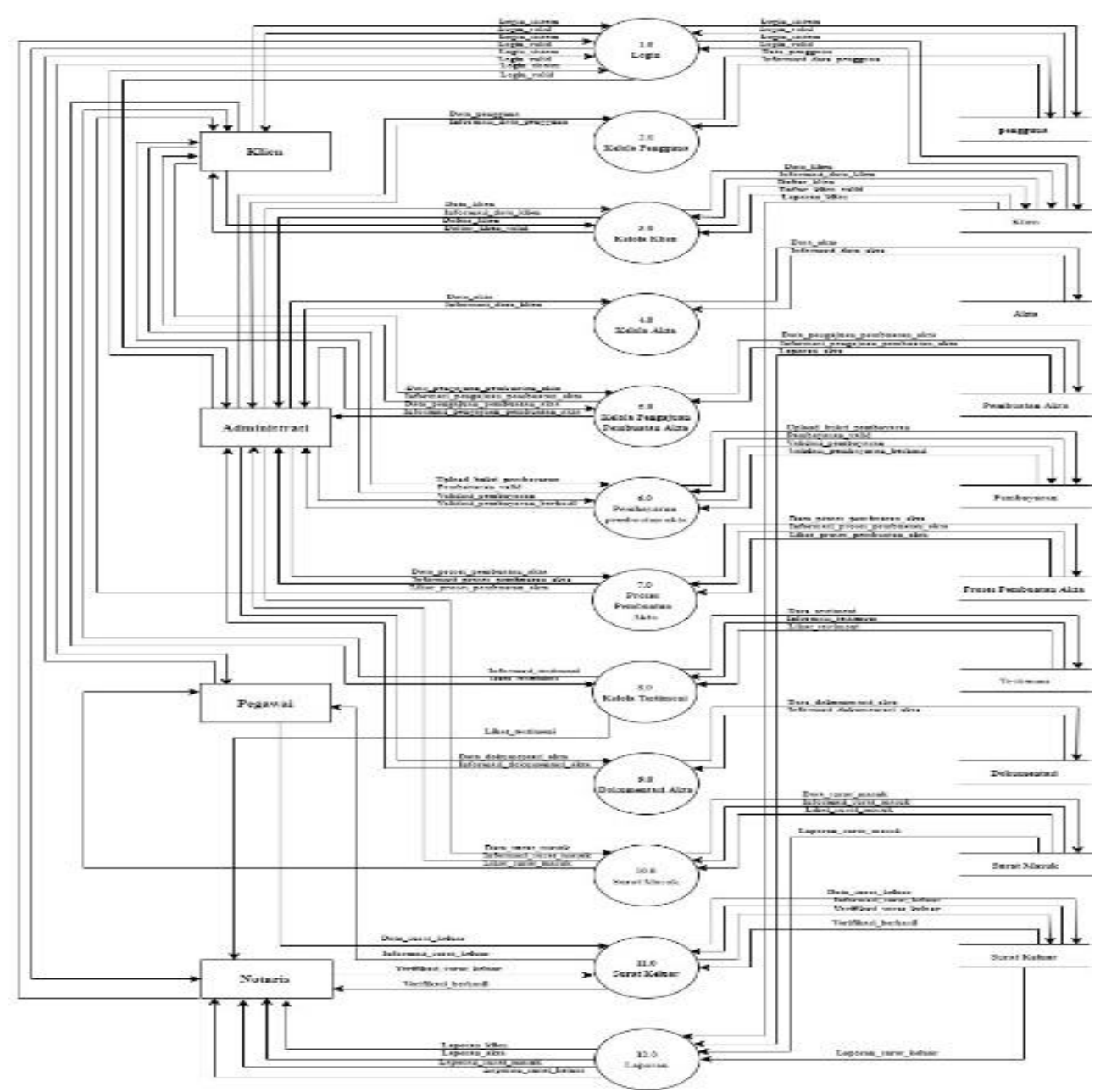

Gambar 4. Data Flow Diagram (DFD) Level Nol Logis

\subsection{Data Flow Diagram Level Nol Fisik}

Berikut adalah gambar Data Flow Diagram Level Nol Fisik pada Sistem Informasi Dokumentasi Berbasis Web pada Kantor Notaris/PPAT Merliansyah, S.H., M.Kn 


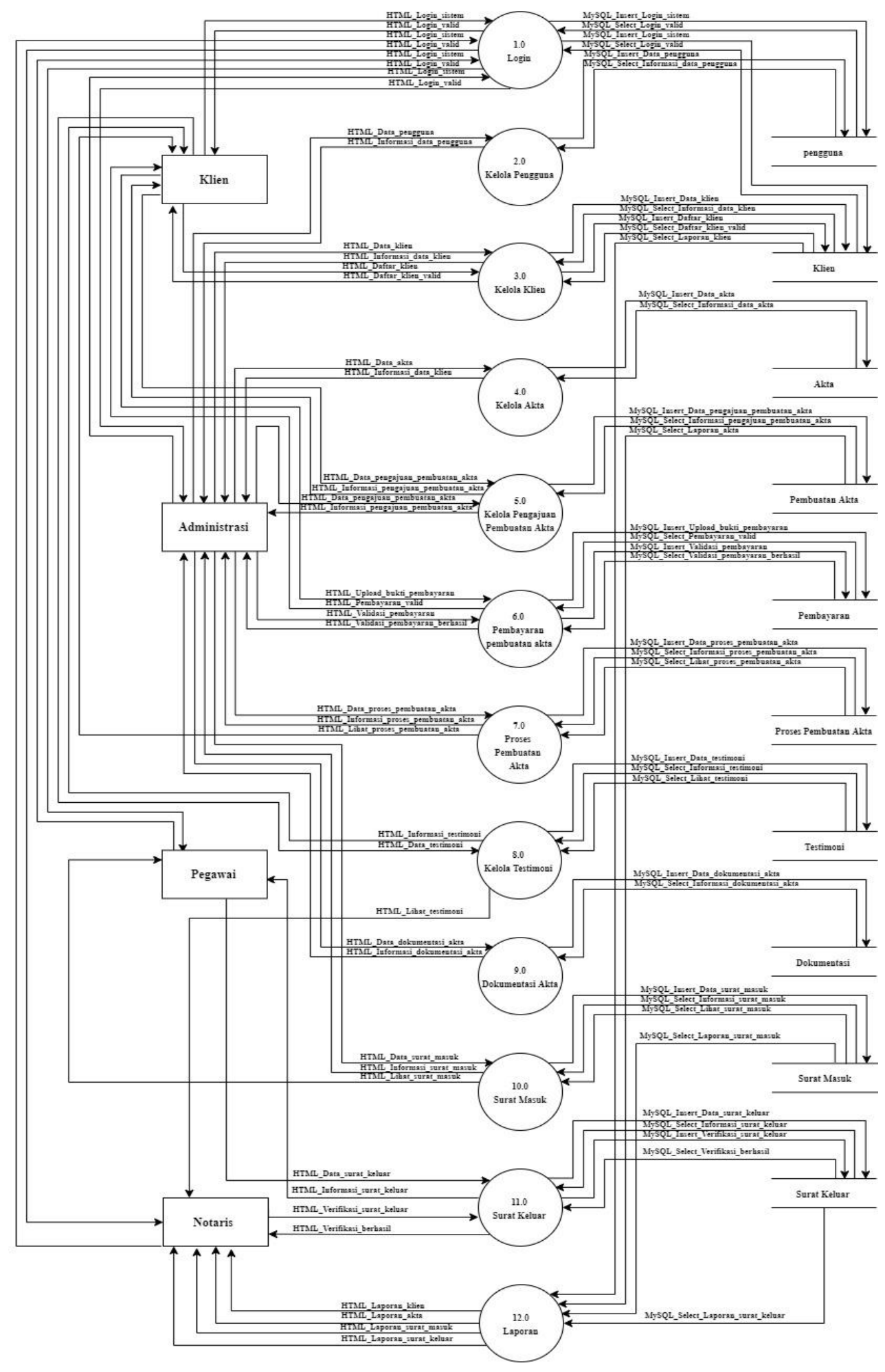

Gambar 5. Data Flow Diagram Level Nol Fisik

\subsection{Tampilan Antarmuka Sistem}


Berikut adalah salah satu gambar tampilan antarmuka Sistem Informasi Dokumentasi Berbasis Web pada Kantor Notaris/PPAT Merliansyah, S.H., M.Kn.

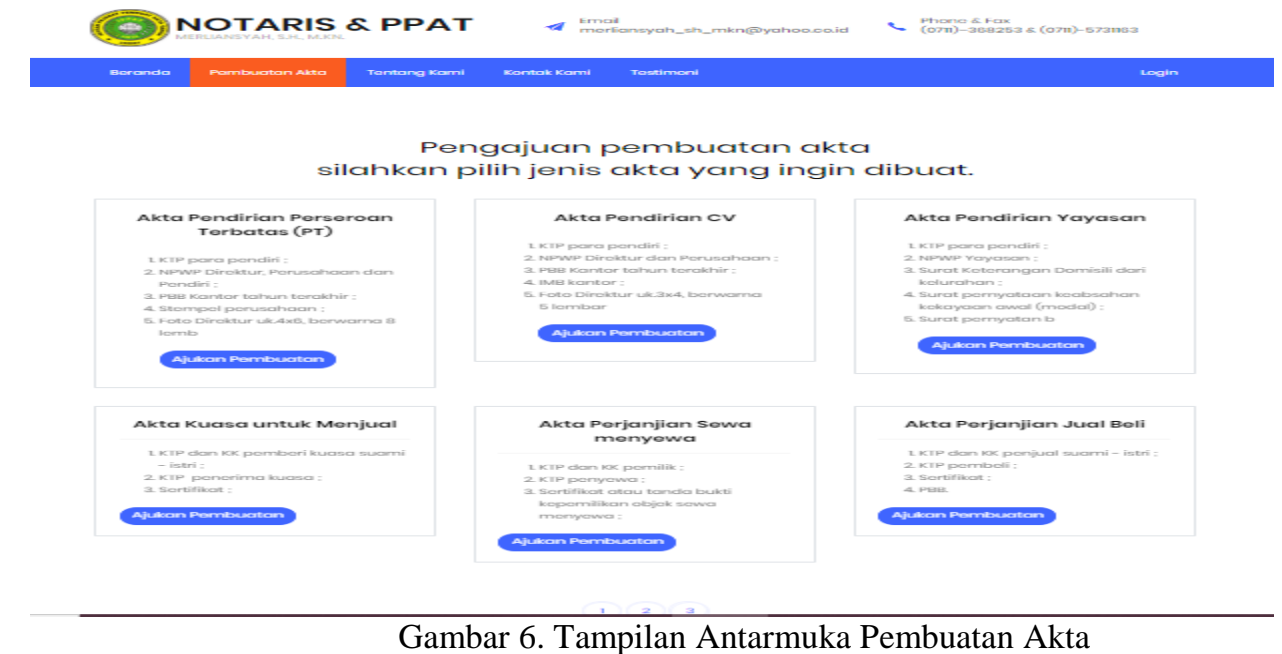

\section{PENUTUP}

\subsection{Kesimpulan}

berikut :

Berdasarkan hasil dari laporan yang telah dibuat, maka didapat kesimpulan sebagai

1. Dengan adanya sistem informasi dokumentasi dengan salah satu bentuk fitur pengajuan pembuatan akta yang memfasilitasi klien untuk tidak datang berkali-kali ke kantor.

2. Dengan adanya sistem informasi dokumentasi, maka dapat mempermudah dalam proses pembuatan laporan bulanan ke Kementrian Hukum dan HAM.

3. Dengan adanya sistem informasi dokumentasi, maka dapat mempermudah pegawai dalam mendapat kan informasi mengenai surat masuk dan mempermudah dalam pembuatan surat keluar.

4. Dengan adanya sistem informasi dokumentasi, maka data-data mengenai pembuatan akta dapat di dokumentasikan dengan baik.

\subsection{Saran}

Dalam perancangan dan pembuatan sistem yang secara teori telah dijelaskan dalam laporan ini, penulis menyadari masih terdapat kekurangan maka dari itu penulis memberikan saran yang dapat digunakan untuk pengembangan Sistem informasi dokumentasi berbasis web pada Kantor Notaris/PPAT Merliansyah, S.H., M.Kn , yaitu :

1. Sistem yang dikembangkan nantinya dapat mencakup semua proses dalam pembuatan semua akta yang tersedia dikantor.

2. Sistem yang dikembangkan nantinya dapat men dokumentasikan semua data - data yang ada.

\section{UCAPAN TERIMA KASIH}

Penulis mengucapkan terima kasih kepada semua pihak yang telah memberi dukungan terhadap penelitian ini. 


\section{DAFTAR PUSTAKA}

[1] AS, Rosa. (2013). Rekayasa Perangkat Lunak Terstruktur dan Berorientasi Objek. Bandung: Informatika.

[2] Dantes, Gede Rasben. Setemen, Komang. Dkk (2019). Pengantar Basis Data. Jakarta: Rajawali Pers.

[3] Fathansyah. (2018) Basis Data Revisi 3. Bandung: Informasi.

[4] Fatta, Hanif. (2007). Analisis Perancangan Sistem Informasi. Yogyakarta: Andi Offset.

[5] KBBI, (2019). Kamus Besar Bahasa Indonesia (KBBI). [Online] Available at: Diakses 19 September 2019, dari https://www.kbbi.web.id/rekapitulasi.

[6] Kemendikbud, Bapenmda. (2011). Kamus Bahasa Indonesia Untuk Pelajar. Jakarta: Bapenmda Kemendikbut.

[7] Marakas, George M. O’Brien, James A. (2017). Buku Pengantar Sistem Informasi, Buku 1, Edisi 16. Jakarta: Salemba empat.

[8] Rawung, Frangky. (2017). Buku Pintar Aplikasi SMS dengan PHP dan MySQL. Yogyakarta: Gava Media

[9] Sutabri, Tata. (2016). Sistem Informasi Manajemen, Edisi Revisi. Yogyakarta: Andi Offset

[10] Simangunsong, Agustina. Sistem Informasi Dokumentasi Berbasis web pada Perumnas Regional I Medan, STMIK Pelita Nusantara, 2018, Medan. 